\title{
WASTE MANAGEMENT WITH THE WASTE BANK SYSTEM IN THE SINDANGRASA VILLAGE
}

\author{
Purnomosutji Dyah Prinajati \\ Universitas Sahid, Indonesia. \\ iinsoekandar@gmail.com
}

\begin{abstract}
The purpose of this activity is to improve the economy and environmental sustainability by the two partners, namely Trash Simpati and Housewives of RW 09 Sindangrasa, East Bogor District, West Java Province. All this time, the two partners have been running a waste collection business using the Waste Bank System, which is obtained from waste in the RW 09 Sindangrasa, East Bogor District, West Java Province. The problem faced by the two partners is the generation of rubbish generated from household rubbish which usually piles up around residents' homes or dumped on river banks around Sindangrasa Sub-District. For this reason, a waste management system needs to be implemented, namely with the Waste Bank. The solution of this program is (1) Initial Socialization, (2) Technical Training, (3) Implementation of the Waste Bank System, (4) Monitoring and Evaluation, and (5) Development. The program target to be achieved in this activity plan for the two partners is to increase public knowledge about waste management with a garbage bank system by up to $90 \%$. Community skills to manage waste up to $60 \%$. Economic aspects of the community with additional income from the garbage bank up to $40 \%$. To ensure the success of the program an evaluation will be carried out at each stage of the development of the program and after the garbage bank can run it will continue to be monitored and facilitated so that it will continue to develop through several programs that can be accessed from both internal and external communities.
\end{abstract}

Keywords: Management, Waste Bank, Sindangrasa Village

\section{INTRODUCTION}

Sindangrasa Urban Village is one of the villages located in Bogor City, where it is located in the Ciliwung River Basin (DAS) where the community is accustomed to throwing garbage into the Ciliwung River. Based on population administration data, the population of Sindangrasa Subdistrict, East Bogor Subdistrict has a population of 12,117 inhabitants, so that the Sindangrasa Subdistrict has a fairly high population density, thus the amount of waste generated is high. To reduce the amount of waste, especially rubbish generated from household activities, it is necessary to manage waste using a garbage bank system. Population density in Bogor City until 2013 reached 8,606 people / Km2. The district with the highest population is West Bogor with a population of 223,168 people (BPS Bogor City, 2015).

\section{METHODS}

\section{Approach method}

Based on the problems that have been described previously and the agreement between the proposing team and partners, the solutions offered to overcome the existing problems can be done using the following approach methods:

1. Initial socialization, providing introduction and basic knowledge about waste banks to the public.

2. Technical Training, a follow-up meeting with a detailed explanation of the standardization of the garbage bank system, the working mechanism of the garbage bank, the benefits of the garbage bank system.

3. Implementation of the garbage bank system, examination of the readiness of the operation of the garbage bank

4. Monitoring and evaluation, providing assistance so that the managed waste bank runs well

5. Development, expanding the waste bank based on the results of monitoring and evaluation

\section{Work procedures}

To support the realization of the methods offered, it can be detailed the work procedures of the PKM waste management activities with the waste bank system as follows:

1. Carry out training activities / mentoring resource motivation

2. Carry out a detailed explanation of the standardization of the garbage bank system, the working mechanism of the garbage bank, the benefits of the garbage bank system. 


\section{Activity plan}

To implement the empowerment method, the stages of empowerment activities are carried out with the following steps:

a. The first stage, collecting data, facts, and information relating to the problem of objects of community service.

b. The second stage, formulating a joint plan through a focused discussion approach. In this process all stakeholders are involved. The purpose of this discussion is to get support and agree on a solution to the problem together.

c. The third stage, preparing a work plan. The results of the focused discussion are included in the strategic plan matrix tables. The matrix will describe the objectives of the activity, location, scope, roles of related parties, planned costs needed, indicators of success and the sustainability process after the mentoring.

d. The fourth stage, the implementation technical plan that contains a detailed time table in a large table. It is expected that all interested parties know the plan to be carried out. In this way all resources are involved in the management process which includes: planning, organizing, reporting and monitoring.

e. The fifth stage, the implementation of activities that have been planned and agreed with partners.

f. The sixth stage, monitoring evaluation and reporting. At this stage also carried out dissemination of the results of the implementation, so that a thorough evaluation can be carried out, discussing sustainability, and development efforts. Dissemination is also intended to provide a learning process for other activities. All subsequent activities will be published in the form of national-level scientific articles, so that they will indirectly promote the efforts of the partners.

\section{RESULTS AND DISCUSSION}

\section{Types of trash and handling}

Of the 87 respondents who filled out the questionnaire data, 76 respondents $(86.4 \%)$ stated that the garbage produced most frequently every day was organic waste, namely food waste, vegetable waste, etc. And 11 (12.4\%) respondents stated that the most waste generated was inorganic waste.

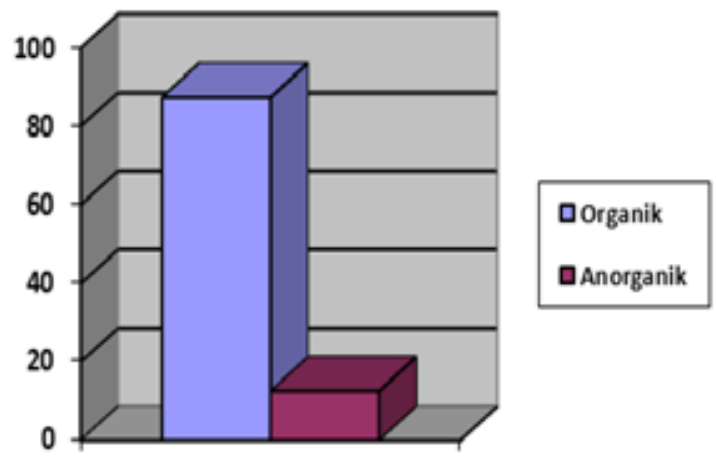

Picture 1 Presentation of amount of organic and inorganic waste

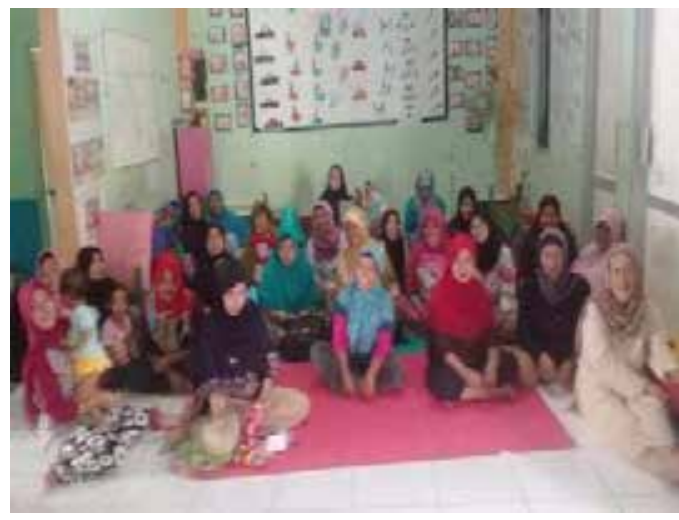

Picture 2. RW09 residents socialization

The type of handling of inorganic waste in the Sindangrasa sub-district of Bogor City is carried out at the Waste Bank and for people who do not participate in the activity of the Waste Bank, the handling of inorganic waste is the same as organic waste, which is transported by a Unit (garbage transportation) every Wednesday to record the amount of waste in the tube by way of weighing the trash and then recorded in a garbage savings book. Conducting socialization to the community RW 09 Sindangrasa Village, the majority of which were attended by residents of housewives / housewives. Introduction to household waste management with a garbage bank system, starting from the source, namely garbage at home. With waste management it will create a clean, healthy and green environment.

Garbage sorting is taught to the community RW 09 Sindangrasa Village, the waste from the source is the residence before being taken to the garbage bank. Garbage sorting is divided into three types namely: organic waste, consisting of leaves and kitchen waste. Inorganic waste, consisting of paper, gardus, plastic, bottles, glass, metal, etc. 


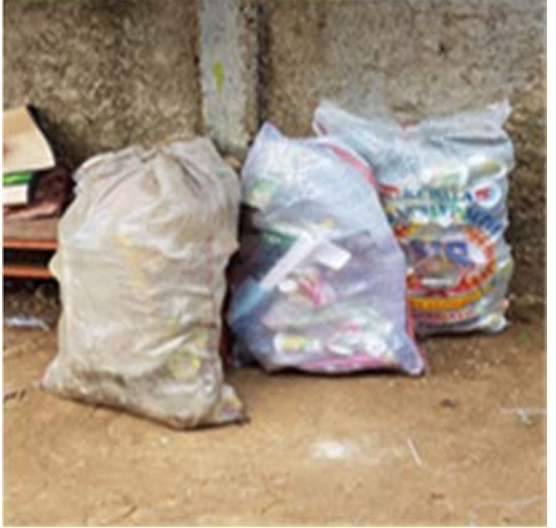

Picture 3. Waste sorting

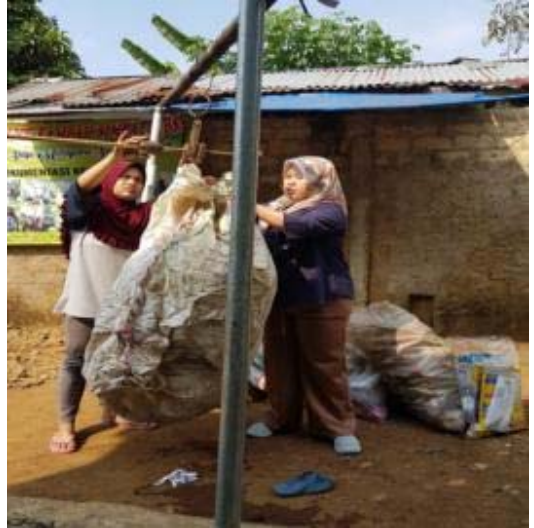

Picture 4. Garbage weighing

Waste weighing is carried out by the management of the garbage bank which is included in the garbage bank customers in Kelurahan Sindangrasa. Weighing is done every Wednesday starting from 14.00 - 16.00. Recording of customers who deposit their waste customers are given a savings book to record garbage deposits.
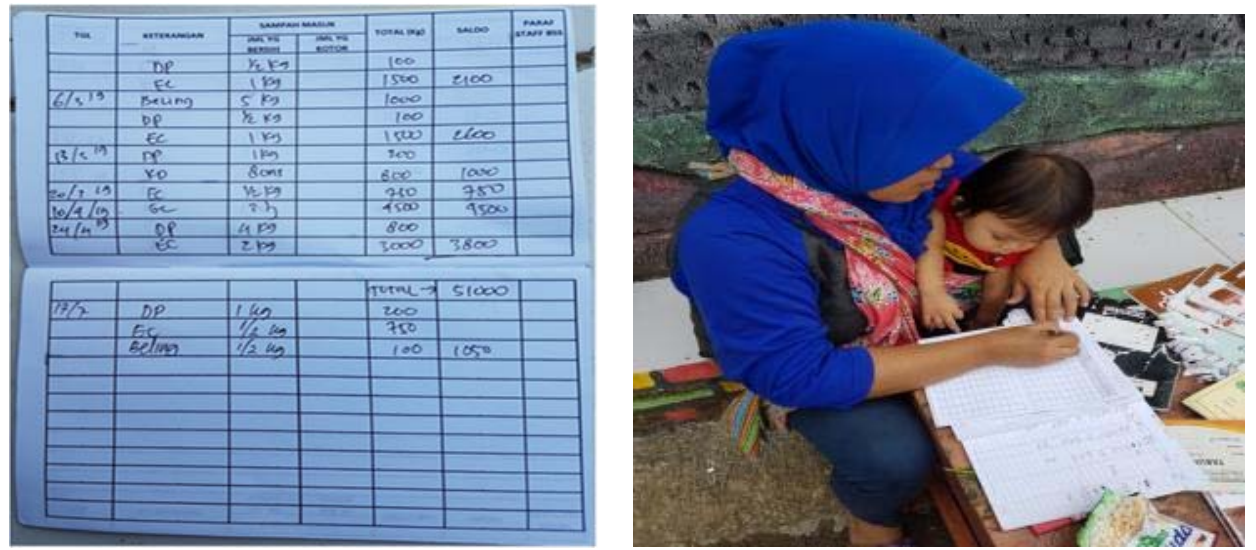

Picture 5. Recording of waste deposit

\section{Characteristics of Respondents}

Respondents in this study amounted to 87 families and are residents of RW 09 Sindangrasa, Bogor City. Socioeconomic characteristics include several variables including gender, age, length of work, final education and income.

Table 1. Characteristics of respondents

\begin{tabular}{|l|c|c|}
\hline Characteristic & Number of Respondent (person) & Percentage (\%) \\
\hline Gender & 12 & 13,8 \\
Male & 75 & 86,2 \\
Female & 0 & \\
\hline Age & 11 & 0 \\
$<20$ & 47 & 12,7 \\
$21-29$ & 29 & 54,0 \\
$30-39$ & & 33,3 \\
$>40$ & 57 & \\
\hline Education & 12 & 65,5 \\
SMA / Equal & 18 & 13,8 \\
DI - DII & 0 & 20,7 \\
S1 & & 0 \\
S2 -S3 & 0 & 0 \\
\hline Length of worked & 7 & 8,0 \\
$<2$ & 36 & 41,4 \\
$2-5$ & 44 & 50,6 \\
$6-10$ & & \\
$>10$ & & \\
\hline
\end{tabular}




\begin{tabular}{|l|c|c|}
\hline Characteristic & Number of Respondent (person) & Percentage (\%) \\
\hline Income & 24 & \\
< Rp 1.000.000 & 40 & 27,6 \\
Rp 1.000.000-Rp 5.000.000 & 23 & 46,0 \\
Rp 5.000.000-Rp 10.000.000 & 0 & 26,4 \\
> Rp 10.000.000 & & 0 \\
\hline
\end{tabular}

Based on Table 1 it can be seen that the number of male sex respondents is 12 people (13.8\%) and the number of women is 75 people $(86.2 \%)$. Hereby, it is known that female sex dominates because garbage bank customers are dominated by women. The age of respondents is mostly dominated by the age range of 30-40 years, because there are still many young people who are less interested in participating in the activities of the garbage bank and the majority of respondents are housewives. The last education of the respondents varied, starting from the level of high school / equivalent, DI - DIII, and S1. Most of the respondent's final education is dominated by high school / equivalent. The longest period of work for respondents is $>5$ years and the majority of respondents' income is dominated by Rp. 1,000,000 to Rp. 5,000,000. The level of Education and Employment is one that can influence the mindset of the perception of the environment and the waste bank.

\section{Waste bank stability}

Waste Bank stability is seen from the aspect of customers which is increasing every year. Bank Sampah Simpati was established on April 13, 2017 at that time the number of customers was only 11 customers and then officers conducted activities by inviting residents of RW 09 to take part in the Garbage Bank. As of July 2019, there were 170 customers. The figure is quite far from the word Effective according to the Chairman of the Trash Bank considering the number of families in Sindangrasa Kelurahan. The Chairperson of the Garbage Bank and other Officers are working on various ways so that all RW 09 residents can participate in the Garbage Bank program. Because the Waste Bank program is very very helpful to reduce the waste problem that exists in Sindangrasa Kelurahan in particular.

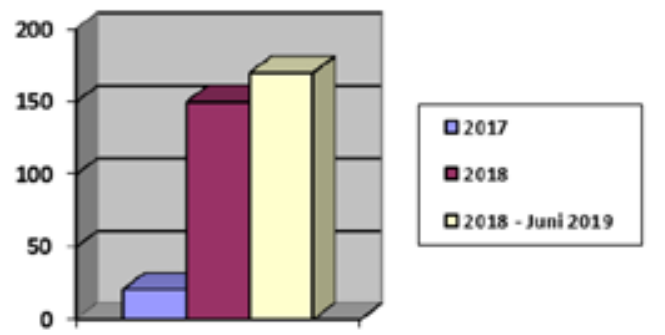

Picture 6. Presentation of the Amount of Waste Bank Customers

And the second month, the operation of customers' garbage banks increased from 11 customers to 32 customers. And in 2017 garbage bank customers increased to 150 customers. In 2018 it increased to 167 and by mid-2019 customers had increased to 170 . This shows a pretty good data considering there are still many residents who have not joined the garbage bank. The inhibiting factor for residents to follow the garbage bank is because the residents do not produce a large amount of inorganic waste and produce more organic waste. While the Simpati Garbage Bank itself cannot yet manage organic waste to the maximum because of the limited costs, space and technology. Also, there are still many residents who have not been able to sort out the rubbish, and there are also many residents who have not yet learned that there is a waste bank activity carried out in RW 09.

\section{Community participation}

Participation or role of the community is seen from how customers deal with their rubbish such as sorting themselves at home before being taken to the weighing scale, bringing waste to the weighing place, and the reason the community does not follow the Waste Bank. The community who participated in sorting waste has reached $100 \%$, meaning that all bank waste customers sort out their own garbage. The number of community participation to come to the garbage bank and do their own weighing is around 7 respondents $(4.09 \%)$, while 164 respondents $(95.91 \%)$ choose to deposit the garbage to the garbage bank officer whose job is to collect garbage. The reason the customer chose not to do the weighing himself was because it was more effective if the garbage was transported by the officer rather than having to carry the waste to the weighing place. 


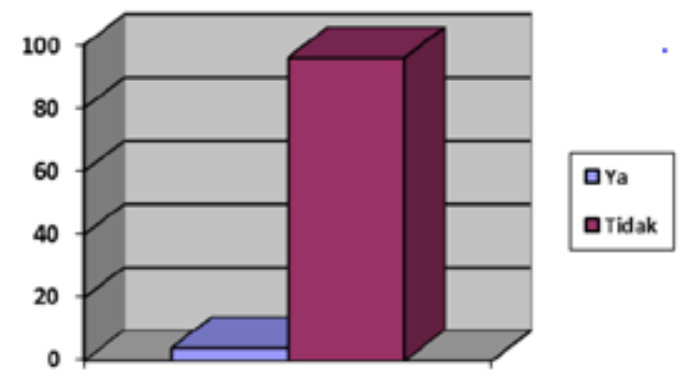

Picture 7. Presentation of Amount of Community Participation

The researcher conducted an interview with the Head of the Waste Bank and 2 respondent residents who were not customers of the Waste Bank about their reasons for not participating in the Waste Bank. And from the two respondents said that they did not produce much inorganic waste so they did not participate in the Waste Bank program. And the Chairperson of the Garbage Bank stated that at present the Garbage Bank officer is working to conduct a Program for Organic Waste that is Composting.

\section{Positive impact of garbage banks}

The positive impact of the existence of a Garbage Bank not only impacts the environment but also impacts economic and socio-cultural values. Of the 87 respondents who filled out the questionnaire $100 \%$ agreed that the impact of the Waste Bank is valuable for the environment, economy and social culture.

Table 2. Respondents' perceptions of the impact of the waste bank

\begin{tabular}{|c|c|c|c|c|c|c|}
\hline \multirow[t]{2}{*}{ No } & \multirow[t]{2}{*}{ Categories } & \multicolumn{5}{|c|}{ Categories of answered (\%) } \\
\hline & & STS & TS & $\mathrm{N}$ & $\mathrm{S}$ & $\mathrm{SS}$ \\
\hline 1 & $\begin{array}{l}\text { Positive impact on environment } \\
\text { 1. Maintain environmental sustainability } \\
\text { 2. Reducing waste heap } \\
\text { 3. Improve environmental aesthetics } \\
\text { 4. Reducing water pollution and flood disasters }\end{array}$ & $\begin{array}{l}0 \\
0 \\
0 \\
0\end{array}$ & $\begin{array}{l}2,29 \\
0 \\
0 \\
0\end{array}$ & $\begin{array}{l}17,2 \\
23,0 \\
28,74 \\
20,69\end{array}$ & $\begin{array}{l}64,36 \\
63,22 \\
45,98 \\
71,26\end{array}$ & $\begin{array}{l}16,09 \\
13,79 \\
25,29 \\
80,46\end{array}$ \\
\hline 2 & $\begin{array}{l}\text { Positive impact on economic } \\
\text { 1. Improve income } \\
\text { 2. Helps buy daily necessities } \\
\text { 3. Help increase the cost of education }\end{array}$ & $\begin{array}{l}0 \\
2,29 \\
13,79\end{array}$ & $\begin{array}{l}0 \\
31,03 \\
25,28\end{array}$ & $\begin{array}{l}73,56 \\
31,03 \\
39,08\end{array}$ & $\begin{array}{l}18,39 \\
32,18 \\
25,29\end{array}$ & $\begin{array}{l}8,05 \\
3,44 \\
8,05\end{array}$ \\
\hline 3 & $\begin{array}{l}\text { Positive impact on social-culture } \\
\text { 1. Increase interaction between citizens } \\
\text { 2. Increase colaboration between citizens } \\
\text { 3. Providing education about the importance of } \\
\text { waste management }\end{array}$ & $\begin{array}{l}0 \\
0 \\
0\end{array}$ & $\begin{array}{l}0 \\
0 \\
0\end{array}$ & $\begin{array}{l}0 \\
0 \\
50,57\end{array}$ & $\begin{array}{l}100 \\
100 \\
49,43\end{array}$ & $\begin{array}{l}0 \\
0 \\
0\end{array}$ \\
\hline
\end{tabular}

Information : STS = Strongly Disagree; TS = Disagree; $\mathrm{N}=$ Neutral; $\mathrm{S}=$ Agree; $\mathrm{SS}=$ Strongly Agree

Based on Table 2, the community has not felt any negative impact from the activities of the Garbage Bank, on the contrary if there is no waste bank activity it will have a negative impact on the environment because the waste management system is only carried out by transport and dispose of it to the landfill. With the existence of the Waste Bank can minimize the generation of waste and prevention to dispose of waste to the river, causing environmental pollution and the spread of disease. In terms of economics the community agrees that the existence of a garbage bank can help improve the economy. Although there are some respondents who disagree, this is because there are still some residents who dump their trash by being transported by trucks then dumped into the landfill. With the existence of a garbage bank, residents can establish friendships and interact with local residents so that it can have a positive impact on residents. The table above shows that most residents agree that the existence of a waste bank can have a positive impact on the environment, economy and social culture. With this, the garbage bank in Sindangrasa Urban Village, Bogor City has managed to have a positive impact on the environment, economy and social culture of the surrounding community. 
Table 3. Results of solid waste and economic value in $2017-2018$

\begin{tabular}{|l|r|r|r|r|r|}
\hline \multirow{2}{*}{$\begin{array}{c}\text { Classification of Solid } \\
\text { Waste }\end{array}$} & \multicolumn{2}{|c|}{$\begin{array}{c}\text { Total of Solid } \\
\text { Waste Heap } \\
\text { (tonnes }\end{array}$} & \multirow{2}{*}{ Price } & \multicolumn{2}{c|}{ Economic Value (Rp) } \\
\cline { 2 - 3 } & 2017 & 2018 & & 2017 & 2018 \\
\cline { 2 - 4 } & 8,665 & 9,058 & 2.300 & 19.929 .500 & 20.833 .400 \\
\hline Dirty Plastic Bottle & 6,500 & 8,946 & 5.000 & 32.500 .000 & 44.730 .000 \\
\hline Clean Plastic Bottle & 8,735 & 3,046 & 1500 & 13.102 .500 & 4.569 .000 \\
\hline Dirty Plastic Glass & 9,035 & 10,362 & 2.000 & 18.070 .000 & 20.724 .000 \\
\hline Clean Plastic Glass & 8,349 & 6,876 & 2.300 & 19.202 .700 & 15.824 .800 \\
\hline Bottle Cap & 3,230 & 3,550 & 4.000 & 12.920 .000 & 14.200 .000 \\
\hline Gallon Cap & 2,450 & 1,758 & 1.500 & 3.675 .000 & 2.637 .000 \\
\hline Bucket & 11,895 & 13,898 & 1.600 & 19.032 .000 & 22.236 .800 \\
\hline Cardboard & 3,450 & 5,985 & 1.400 & 4.830 .000 & 8.379 .000 \\
\hline Paper & 1,020 & 1,200 & 2.400 & 2.448 .000 & 2.880 .000 \\
\hline Scrap iron & 0,550 & 1,245 & 10.000 & 5.500 .000 & 12.450 .000 \\
\hline Alumunium & 2,780 & 2,756 & 500 & 1.390 .000 & 1.378 .000 \\
\hline Plastic toys & 6,782 & 8,965 & 400 & 2.712 .800 & 3.586 .000 \\
\hline Glass Bottle & 0 & 0,012 & 60.000 & 0 & 720.000 \\
\hline Refrigerate & 73.441 & 77.657 & & 148.965 .500 & 174.428 .000 \\
\hline TOTAL & & & & &
\end{tabular}

Based on table 3, the potential economic value in 2017 is IDR 148,965,500 and in 2018 that is IDR $174,428,000$ with an increase of IDR 159,462,500. The type of cardboard waste has the highest economic value and the lowest is iron. With this data it is known that for 1 year the economic value of many has increased. This can be a positive impact on customers to increase revenue. Based on table 4.2, the potential for waste generation in 2017 is 73,441 tons and in 2018 is 77,657 tons with an increase of 4216 tons. This is due to the increasing number of needs needed by customers so that the increasing amount of waste. The highest total generation generated by the type of cardboard waste. The amount of waste generation in 2017 to 2018 has increased by $0.95 \%$ and the economic value has increased by $0.85 \%$. That is due to the increasing number of customers at the Simpati Garbage Bank, thereby increasing the amount of waste generation and affecting the amount of economic value. he following are the Amount of Waste Arising and Economic Value obtained from January to May 2019, namely:

Table 4. Economic value of simpati garbage banks in January - May 2019

\begin{tabular}{|l|r|r|r|}
\hline $\begin{array}{c}\text { Classification of } \\
\text { Solid Waste }\end{array}$ & $\begin{array}{c}\text { Total of Solid Waste } \\
\text { Heap (tonnes) }\end{array}$ & \multicolumn{1}{|c|}{ Price } & $\begin{array}{c}\text { Economic Value } \\
\text { (Rp) }\end{array}$ \\
\hline Dirty Plastic Bottle & 0,47025 & 2.300 & 1.081 .575 \\
\hline Clean Plastic Bottle & 0,3435 & 5.000 & 1.717 .500 \\
\hline Dirty Plastic Glass & 0,2885 & 1.500 & 432.750 \\
\hline Clean Plastic Glass & 0,23875 & 2.000 & 477.500 \\
\hline Bottle Cap & 0,18975 & 2.300 & 436.425 \\
\hline Gallon Cap & 0,15495 & 4.000 & 619.800 \\
\hline Bucket & 0,23515 & 1.500 & 352.725 \\
\hline Cardboard & 0,3985 & 1.600 & 637.600 \\
\hline Paper & 0,2895 & 1.400 & 405.300 \\
\hline Scrap iron & 0,0512 & 2.400 & 122.880 \\
\hline Alumunium & 0,05135 & 10.000 & 513.500 \\
\hline Plastic toys & 0,2159 & 500 & 107.950 \\
\hline Glass Bottle & 0,2755 & 400 & 110.200 \\
\hline Refrigerate & 0,003 & 60.000 & 180.000 \\
\hline TOTAL & 3,6666 & & 7.195 .705 \\
\hline
\end{tabular}


Based on table 4, the potential economic value in 2019 during January to May is Rp 7,195,705. The type of clean plastic bottle waste has the highest economic value and the lowest economic value is glass bottle. Glass bottles become the lowest economic value due to the low selling value and also not the amount of waste from glass bottles.

\section{CONCLUSION}

\section{Conclussion}

From the observations of the Simpati Simpati Garbage Bank it can be concluded that:

1. 76 respondents $(86.4 \%)$ stated that the most waste produced every day was organic waste and $11(12.4 \%)$ respondents stated that the most waste generated was inorganic waste.

2. The number of male sex respondents is 12 people $(13.8 \%)$ and the number of women is 75 people $(86.2 \%)$. Most of the respondent's final education is dominated by high school / equivalent. The longest period of work for respondents is $>5$ years and the majority of respondents' income is dominated by Rp. 1,000,000 to Rp. $5,000,000$.

3. Bank Sampah Simpati was established on 13 April 2017 and in 2018 Tphun increased to 167 and in mid-2019 customers increased to 170 customers.

4. The economic value obtained from selling waste to collectors in 2017 is IDR 148,965,500 and in 2018 IDR $174,428,000$. The economic value in 2019 from January to May is IDR 7,195,705.

5. Total waste generation in 2017 was 73,441 tons and in 2018 it was 77,657 tons. Whereas in 2019 during January to May that is 3.67 tons.

\section{ACKNOWLEDGEMENT}

This research was funded by Internal Grant of Sahid University- Jakarta Program 2019 (Contract Number 118.20/USJ-11/H.54/2019). The authors declare that there is no conflict of interest regarding the publication of this article.

\section{REFERENCES}

Azwar, A. (2010). Pengantar Ilmu Lingkungan. Jakarta : Mutiara Sumber Widya.

Asteria, D. dan Heruman, H. 2016. Bank Sampah Sebagai Alternatif Strategi Pengelolaan Sampah Berbasis Masyarakat di Tasikmalaya. Jurnal Manusia dan Lingkungan.

Rahbil, F.A., Gani, M., dan Djamaluddin, I. (2017). Studi Pengelolaan Bank Sampah Sebagai Salah Satu Pendekatan Dalam Pengelolaan Sampah Yang Berbasis Masyarakat (Studi Kasus Bank Sampah Kecamatan Manggala). Jurnal Teknik Lingkungan.

Handayani, D.S,, Budisulistriorini, S.H., dan Nuraini, M.R. (2009). Kajian Nilai Ekonomi Penerapan Konsep Daur Ulang pada TPA Jatibarang Semarang. Jurnal Presipitasi.

Peraturan Menteri Negara Lingkungan Hidup Republik Indonesia Nomor 13 Tahun 2012 Tentang Pedoman pelaksanaan reduce, reuse, dan recycle melalui bank sampah.

Puspitawati, Y dan Rahdriawan, M. (2012). Kajian Pengelolaan Sampah berbasis Masyarakat degan Konsep 3R (Reduce, Reuse, Recycle) di Kelurahan Larangan Kota Cirebon. Jurnal Pembangunan Wilayah \& Kota.

Muhammad, R., Abdi, C. dan Mahyudin, R.P.. (2016). Kajian Bank Sampah Sebagai Alternatif Pengelolaan Sampah Dosmetik Di Kota Banjarbaru. Jurnal Teknik Lingkungan.

Suryani, A.S. (2016). Peran Bank Sampah dalam Efektivitas Pengelolaan Sampah (Studi kasus Bank Sampah Malang). Jurnal Aspirasi.

Suwerda, B. (2012). Bank Sampah (Kajian Teori dan Penerapan). Yogyakarta : Pustaka Rihana..

Undang-Undang No. 18 Tahun 2008 tentang Pengelolaan Sampah.

Unilever Indonesia. 2014. Buku Panduan Sistem Bank Sampah \& 10 Kisah Sukses. Jakarta 